\title{
SOFT FABRIC, BRIGHT WOUNDS
}

\author{
Thomas David Lisk
}

"Not one step has man taken toward the solution of the problem of his destiny." -Emerson, "Friendship"1

THE WAR WAS BLOOD AND BLOODY MUSLIN, ${ }^{2}$ rice and molasses, ${ }^{3}$ blood and gray fragments of lead spattering in a pan, and then the surgeon's exhalation. Once Walt Whitman brought a plug of rough cut shag folded in a green tobacco leaf for each young soldier who smoked. He bought the bundle of green leaves for a dime from a free black man desperately hawking them on Pennsylvania Avenue, not knowing where the black man got them (providence is mysterious) and not knowing what he himself would do with them. He was on his way back to his third floor room on $4 \frac{1}{2}$ Street after a day at Campbell hospital. Because he didn't himself smoke, the scent of tobacco came to him before he was close enough to actually smell it. The bundles of wrinkled green dangling from a string around the man's neck looked like big feathers and turned him into a beautiful dark angel disguised as a tropical tree. Walt had to make contact, touching the black angel's dry palm with the sliver of silver. The angel grinned.

The palmate leaves were as soft as skin and scented his room all night. The next day it pleased him to press the soft packets into the young men's waiting palms: Alcester Congreve, "Chet," with a stiff, blondish forelock and square, stubby hands. Bill Dawley, almost Negroid in coloring but with features like a French aristocrat and-already at age twenty-only a soft black ring of downy hair around his brown head. Lynch Hawkins Pearce, a big handsome boy with a man's big mustache, but so timid he didn't dare ask for anything but made Walt try to read his mind, a task Walt relished because it meant staring into the boy's greenish, long-lashed eyes. Reuben Farwell, ${ }^{4}$ a Michigan lad, called little Mitch. Benton "Ben" Wilson, color-bearer for the 185th New York. William Stanberry and Manvill Winterstein, Ohioans. Bethuel Smith, a wonderful name. Captain Simms of the 51st New York, killed later in the mine explosion at Petersburg. Captain Sam Pooley and Lieutenant Fred McReady, also of the 51st New York.

As he sat in his big rocker by the window at 328 Mickle Street in Camden, one by one they came back to him now, some of them dead 
not long after he kissed their foreheads and bid them good-bye for the day; some recuperated and now older than he himself had been then (though in the 1860s Walt had been only in his forties, looking a decade older and acting slow enough sometimes to be mistaken for seventy); some missing fingers or limbs and bearing scars and memories deeper than anything Walt brought; some writing to him on the twenty-fifth anniversary of Appomattox; some coming now and then to visit him in this afterlife.

Still, it pleased him to think some of the others might remember him, the ones who didn't come, might remember the coarse patter of spring rain on the coarse, creamy-colored canvas of the hospital tent, the feeling of tenuous security when old Walt ducked in and shook the drops from his sombrero, smiled, said, "Howdy, boys," and went from bed to bed dispensing lemon drops or dimes, "oranges . . ., sweet crackers, figs," "amusing reading matter," writing paper with a stamped envelope, a "stick of horehound candy," "a little jar of raspberries," tobacco, or ripe apples ${ }^{6}$ warm from his pockets as if he'd picked up windfalls on a sunny early autumn day and kept them incubating sweetness in his baggy gray wool jacket or his ample rucksack. Maybe some of them remembered him.

“How come you're wearin' gray, Walt? You ain't a reb, are you? Not with that New York twang."7 And he resisted the temptation to josh back that many who'd read the Leaves thought him a rebel more dangerous than any half-formed lad in a mismatched gray uniform. Resisted the impulse to call his own garb Quaker gray, because some of the boys wanted to pray, to go after God, begging for help instead of waiting in silence for the still, small voice. Walt's own voice was neither still, small nor identifiably from New York.

Maybe some former boy-soldier remembered Walt holding his hand in two of Walt's, remembered Walt closing his own eyes while the boy, eyes too clamped shut, prayed his ma and pa be well cared for, prayed that mama not know how bad off he was with an empty space on the left side of his bed where his leg ought to have been. Walt did not think of "ought," thought always of "is," the steamy heat of Virginia summer in the tents, the days so sultry no breeze stirred and all the boys had their bandaged wounds uncovered by sheets or blankets and Walt carted around an oak bucket with a long-handled tin dipper and the coolest water he could fish from the Rappahannock, draped his own coat over the foot of the first cot and tied a wet kerchief around his neck to keep him from getting woozy himself. "Would you like a cool drink, my dear?"8 he'd say, bending like an angel over each cot. Memory is, just as experience is.

Maybe some of them would remember him writing letters for them when their fingers wouldn't hold a quill or their eyes wouldn't focus or 
they couldn't sit up, or just plain didn't know how to write or read: "gunshot wound in the breast, cavalry skirmish, taken to hospital, / At present low, but will soon be better." On cold days with his own big pink fingers almost blue, he wrote their skimpy stories for them, the horrors carefully deleted and the dangers underplayed so folks back home wouldn't worry; wrote with pride of heroic minor wounds and with chagrin of heroic diarrhea; wrote love letters and husband-to-wife letters, and once in a great while carried away a telegraphic message to send in a hurry; wrote the words that said above all one thing-I'm alive, thank God-and when that reassurance wasn't possible, used the address and truncated personal missive, adding his own postscript to tell the boy's parents their son had died peacefully, a brave, well-beloved soldier, not mentioning that he died of dysentery or typhus, pleurisy or septicemia. And back in his own room, "Garret it literally was, containing hardly any more furniture than a bed, a cheap pine table, and a little sheet-iron stove in which there was no fire," ${ }^{10}$ he'd write his own Ma, assuring her he was hale and hearty but there was so much to do. And she wrote back asking him for any help he could give her, money being tight there in New York. And meanwhile he was writing to everyone he could think of, begging for bits of alms to support the work he was doing, appointed by no one but himself, funded by no government and praised by no one but the looks in the sick boys' eyes.

Nearly thirty years later, some nights in May and June, Walt sat in his rocker and through an open window listened to the sounds of Camden. Sometimes he fancied long, straight Mickle Street was a telegraph wire, fancied he could separate the general ruckus across the river from sounds nearer by, could hear music from the park, could pick out the noise of horses from the noise of voices the way the nurses could separate linen from muslin, wool from silk - but of course there was no silk and very little wool - the bandages were the cheapest stuff available, clean but not sterile, white or natural ecru. Soft as a cheek was some of the fabric, but it muffled the touch as it stanched the wound, diffused the electricity into the air before it could pass from flesh to flesh, exciting him almost unbearably. Once he watched a woman nurse gently holding soft muslin to the mouth of a young man hemorrhaging convulsively and hawking up blood, Walt feeling himself curiously detached and at the same time touched by her tenderness, more touched by the tenderness than by the blood, so what he remembered now was the feeling, the soft hands and the soft cotton, the inherent beauty of a strong woman, of selfless love. Then came the angel of death, the Strong Deliveress.

The war was not one story but a train of images in a shifting atmosphere of feelings governed by Walt's peculiar confidence in his own wholeness. But the war was also a feverish whole that no one soldier's story could represent because each boy's story did represent it, told it far 
better than history books yet to be written in 1863 but by 1890 full of glory and grandeur and righteous indignation, tempered by the almost universal conviction that Robert E. Lee-white-haired, white-bearded, dressed in gray - was a strategic genius and a fine gentleman to boot, and in order not to seem a pathetic amputation of an eternal identity, each boy's story had to be connected with that glorious, vainglorious, inglorious whole.

"I came to this thing because I wanted to free the niggers," vate Daniel Otis Wright told him, then explained he was a Vermont farm boy who came to New York to join the 51 st because he fought with his father, who thought Africans were monkeys but hated the idea of breaking up the Union. And so to spite and please his father the boy ran away to fight. The war was not black and white. And in a prisoners' ward Walt listened to Corporal Martin Chandler from Stateburg, South Carolina, tell about a plantation run by blacks in his home town, ${ }^{12}$ assuring the old gray Yankee the slaves didn't have such a bad life, especially when they were owned by another black. Talked with black soldiers in blue uniforms who told him there were blacks in gray uniforms too and to Private Nathaniel Washington in particular who said, "You don't know what it is not to be free, man. You can't. You can't. You white," and shook his head with a rueful smile. (Whitman was undeniably white; his very name proclaimed it.)

Walt stepped between the cots as slow and easy as molasses, moved in the stench of fevered guts and the salty tang of sweat and blood, the waxy smell of canvas and the clean scent of lye soap, finding his path among atrocities and contradictions, the pile of severed limbs ${ }^{13}$ waiting to be carted off from the hospital and the white curtains drawn up like summer clouds over the soldiers' beds; Walt doing his little bit of good while young boys were starving at Andersonville and dying in the Wilderness or on gentle landscapes charged with horror. All the landscapes where the fighting went on were gentle: awful rolling hills, meadows rimmed with woods, fields where in living memory farmers followed plows and swatted flies. Now flies clustered in the tents seeking the seeping linen, hoping to feed and recreate themselves, and the curtains had to be lowered around each bed to spare the suffering patients as much as possible from the minor annoyance of houseflies. "Once in a while some youngster holds on to me convulsively, and I do what I can for him; at any rate, stop with him and sit near him for hours, if he wishes it," 14 Walt wrote.

But it never occurred to Walt to write about a fly buzzing while he died, or to imagine himself dying, never occurred to him to put his feelings into common meter-the rhythm of the lyrics to Protestant hymns - to describe the way the light came in through the tied-back tent flaps or flickered from an occasional candle lit by a nurse checking her patients as Walt at the other end of the room gathered himself to- 
ward the door to take the train back to the District to spend his own candlelit evening writing letters to everyone he could think of, asking for money to keep up this work.

They ate rice because it kept better than bread or potatoes, though they had salt pork and hardtack and sometimes even real bread and potatoes and meat it was surprising they could relish so, having smelled so much putrescence, seen so much carnage. But they needed the meat to get back the strength to heal wounds that for a time turned them into raw meat before most of them were properly men. Some thought their wounds had made them men. But there were fewer wounds than diseases and less meat than starch. Rice kept forever as long as you stored it dry and safe from weevils and worms. And the doctors still used bloodsuckers to clean wounds and stop the bleeding, gunmetal gray slugs of slippery flesh it was hard to tell head from tail. But they did their work, and the wounds they sucked healed quicker, cleaner than the ones merely wiped with a square of muslin after the surgeon withdrew his unwiped scalpel and plunged it into the next patient.

It was a hell of a war, a hell of a time, but out of it all came a transcendence, an identity from two fragments of what was to Walt obviously one whole. Hell, the Confederates even named themselves as if to admit they were with the Federals, the Union troops. But it was an identity in tension, wounded, healed and scarred, limbs reattached that didn't think they wanted to be reattached and moved stiffly ever after. Walt wrote that his diary of the war was "convulsive," but "[t]he war itself, with the temper of society preceding it, can indeed be best described by that very word convulsiveness." 15 Perhaps not surprisingly, Nathaniel Hawthorne-though he was something of a Copperheadused the same word:

In a letter to a friend on the war he admitted that "I always thought that it should have been avoided," and that it would "only effect by horrible convulsion the self-same end that might and would have been brought about by a gradual and peaceful change." But this was not a view he emphasized publicly. ${ }^{16}$

The Whitman of my imagination moves toward the Whitman of fact, of history.

His benevolence to the sick and wounded soldiers during a great part of the civil war is an old and often repeated story, but in this he was to a great extent the almoner of others. His self-sacrificing labors as a volunteer visiting nurse were his own free-will offering, and from them came his long years of suffering, for his early paralysis was the result of these exhaustive and unremitted efforts.

"His devotion surpassed the devotion of woman."17 
In Specimen Days, Whitman himself estimated that during the three years he spent in field and camp hospitals during the war he made over 600 visits and saw 80,000 to 100,000 sick and wounded: "These visits varied from an hour or two, to all day or night; for with dear or critical cases I generally watch'd all night." 18 For dear cases.

He gravitated to teamsters and visited black soldiers, he says. ${ }^{19}$

Sometimes I took up my quarters in the hospital, and slept or watch'd there several nights in succession. Those three years I consider the greatest privilege and satisfaction (with all their feverish excitements and physical deprivations and lamentable sights,) and, of course, the most profound lesson of my life. I can say that in my ministerings I comprehended all, whoever came in my way, northern or southern, and slighted none. It arous'd and brought out and decided undream'd-of-depths of emotion. It has given me my most fervent views of the true ensemble and extent of the States. . . . I was with more or less from all the States, North and South, without exception . . . . and found, during those lurid years 1862-63, far more Union southerners, especially Tennesseans, than is supposed. ${ }^{20}$

Black divided and confederated white.

Walt spent a lot of time in Washington hospitals, "in Patent-office, Eighth street, $\mathrm{H}$ street, Armory-square, and others," 21 including Campbell hospital. He visited a brick mansion used as a hospital on the banks of the Rappahannock in Falmouth, Virginia, and took the "Aquia creek railroad, and so on government steamer up the Potomac" back to Washington. On his southern junkets he took trips through the camps, "Sometimes at night among the groups around their fires, in their shebang enclosures of bushes. These are curious shows, full of characters and groups," 22 he says, but he gives no examples. "I soon get acquainted anywhere in camp," he says, "with officers or men, and am always well used." 23

As he got off the steamer and set foot on shore, as he stepped off the train into the South, as he wandered among the bivouacked soldiers in their brush huts and tents, he felt light and free as a bird.

Diagonally opposite to [Lincoln's Secretary of the Treasury, Salmon P.] Chase's great house, on the corner of $\mathrm{E}$ and 6th streets, stood one of those old wooden buildings which then and for some years afterwards lingered among the new and handsome blocks rising around them, and made the "city of magnificent distances" also a city of astonishing architectural contrasts. In the fine large mansion, sumptuously furnished, cared for by sleek and silent colored servants, and thronged by distinguished guests, dwelt the great statesman; in the old tenement opposite, in a bare and desolate back room, up three flights of stairs, quite alone, lived the poet. Walt led the way up those dreary stairs, partly in darkness, found the keyhole of a door which he unlocked and opened, scratched a match, and welcomed us to his garret.

Garret it literally was. . . . ${ }^{24}$ 
This afternoon, July 22, 1863, I spent a long time with a young man I have been with a good deal from time to time named Oscar F. Wilbur, company 6, 154th New York, low with chronic diarrhea and a bad wound also. He asked me to read him a chapter in the New Testament. I complied, and asked him what I should read. He said "make your own choice." I opened at the close of one of the first works of the Evangelists and read the chapters describing the latter hours of Christ and the scenes of the crucifixion. The poor wasted young man asked me to read the following chapter also: how Christ rose again. I read very slowly, for Oscar was feeble. It pleased him very much, yet the tears were in his eyes, and he asked me if I enjoyed religion. I said, "Perhaps not, my dear, in the way you mean, and yet maybe it is the same thing." 25

At 328 Mickle Street in Camden, New Jersey, in June 1890 Mary Davis's canary twittered in its cage, the twittering not quite a song, but not a human yawp either. Mary Davis kept house for Whitman. Yes, a man can be happy no matter how straitened his circumstances. It's summer. It was summer.

Having struggled with a consistent and comprehensive identity, Walt knew how difficult it would be to be God, never mind to comprehend that identity. (Being is easier than comprehending.) Walt had worked to make himself imperturbable, to inure himself to the pain of an uncertain knowledge that comes late at night sometimes with crushing certainty: no self endures, no thing is immortal. Even the rolling tides, the renewing grass that he had said proclaims there is no death, these things too shall pass.

Two scruffy boys about six years old from across the street are amusing themselves by climbing up the wedge covering the opening to the cellar of 328, climbing up and sliding down. The whole slide is barely the length of a man's body. Walt can hear the resonant thump of their bare feet on the slanting doors, which boom like a drumhead, the cellar, the whole house resonating like a drum. I watch and wait, he thinks, I watch and wait. Mary might have one of her headaches, might take the throbbing of the doors as a macrocosmic echo of the throbbing in her head. ${ }^{26}$

But Walt had told her to let the children alone. He liked to see their heads pop up at his front-room window downstairs, to see their dirtsmudged cheeks and bright eyes. "You're only young once," he'd say to Mary, his own eyes brightening. "They won't be at it long." And they never were. Nor in all the years he lived, he died, at 328 Mickle Street were they always the same children. But different children became the same children. Half the kids from the neighborhood had been warned: "Don't ever go into that house!"27

But you may climb up and slide down the cellar door. "I am large, I contain multitudes." 28

Once when stately Tom Donaldson came to Whitman's house, from across the street he heard "a bundle of dirt with bread and sugar upon it" shout out, "Hurry, Mama! A fat man at Whitman's door!" And after 116 
a pause, Donaldson heard the mother bellow back, "Jimmie, watch if he comes out!" 29 The myth that mighty Mickle was a maw, a bourne from which no traveler returned, joined the kids' mythology. The very cellar might be filled with mummies moldering in the New Jersey dust, or the front hall might be a passageway to undreamt-of mysteries it would take Edgar Poe to do justice to.

Still they popped their tousled heads up at his window, and once in a while Walt fished in his pocket for a precious liberty dime and they scampered off to the little store at the corner and came back later with even more dirt on their sticky faces and grubby fingers. "I could use you for fly paper," Walt told one of them. Corrupting to youth he was, always had been, because he said the simple thing, "You're as alive now as you'll ever be." ${ }^{30}$ They were real children and they weren't, the latest ephemeral versions of the shifting and recurring self, one of the perpetually dying phases of identity out of which identity is always becoming.

Scores of times I have sat at one window of his front room or parlor, he at the other, and seen and heard the school children as they climbed up the cellar door, look into the room and call out: "How are you to-day, Mr. Whitman?" He would answer cheerily: "All right, my dear; is that you Johnny, or Sally?"- as the case might be. ${ }^{31}$

Give these boys something to ease their suffering, he thought of the invalids in the field hospitals. To mark their happy lives, he thought of the kids on the brown, angled cellar door. Mary Davis, Mrs., had no kids of her own, only Harry and Warry who called her "Mother." Like Walt himself she was impenetrable and lost her husband almost before they were married, before they ever lived together. But once and forever, Mary Oakes became Mary Davis and never stopped caring for others to make up for not having been cared for herself. Eternal recurrence, Goethe called it (Walt thought, vague about concepts): the way the individual perpetuates the species, the way our identities are reduplicated not just by our mating bodies but by our emotions, the dreamlike identities through which we face each other and call what we know "the world."

Mary always had someone besides Walt: Harry and Warren, Captain Fritzinger's boys, who stayed away at sea as much as they could, but always came back to her. Warry with his cat-like grin and a little pointed mustache she hated. Harry with his fatherly detachment and unwillingness to beg for love but only to present himself to Mary and hope. . . . Annie Dent, ${ }^{32}$ the colored girl Mary found and found a place for in the crowded house. With her black Topsy locks against the blackflecked white of Walt's wolfskin robe, Annie's feet wouldn't touch the ground and she looked like a character in a fairytale. 
When Whitman first came to us on his return from the seat of war, he was, he said, continually thinking: How would all this have looked to Emerson,- -how would he be affected by such scenes, how would he act, feel, seem, under these conditions? Would he keep that calm and sweet exterior? ${ }^{33}$

It was from Walt Whitman that [Louis] Masur takes his rather awkward title ". . . the real war will never get in the books. "It is not clear what Whitman meant by "real war." $\mathrm{He}$ claimed to have "seen war-life, the real article," and to "have been on the battlefield among the wounded," though in fact he had never seen a battle. What he had seen much of, and graphically described, was the daily life of the army hospitals of Washington that made the war seem "a great slaughter-house." At times it "horrified and disgusted" him. On the next page he could say that the sight of cavalry on the march "made my heart leap" because "it had the look of real war." Was the real war one or the other, or both? The poet shared the ambivalence of political conservatives about slavery and about the South. He was impatient with abolitionists: "Besides," he wrote, "is not America for Whites? And is it not better so?"34

\section{A broadside issued in Hartford, Connecticut in October 1835:}

Considering that it is no less the duty than the right of freemen, to express their sentiments on all questions materially affecting the prosperity of the country or the maintenance of its liberties and free institutions; and regarding the moral force of public opinion on the basis and primary elemental principle of our government, the Citizens of Hartford cannot view with indifference the excitement which now prevails on the subject of slavery in the United States.

This excitement has been occasioned by the rash and reckless measures and proceedings of the Abolitionists of the Middle and North States. We believe that these proceedings will result in no good, but much evil; that their direct and obvious tendency is to agitate and alarm the people of the slave States; endanger their peace and security, if not expose them to the evils and horrors of insurrection, massacre and servile war-to injure the slave population and subject them to restrictions and severities from which they have hitherto been exempt, and greatly defer, if not wholly extinguish the hope of the final amelioration of their condition - that they tend to destroy that reciprocal harmony and confidence which should prevail among the people of different sections of the Union; to embarrass commercial and social intercourse among them, to alienate their minds and to "weaken those sacred ties which hold together its several parts." 35

Bandages protected the sensibilities of the unmutilated, but did little to heal the wounds they covered.

It is not probable that $\mathrm{Mr}$. Whitman received from all contributions in this hospital work in 1863, 1864, and 1865, all told, to exceed seven thousand dollars. The rest he supplied by his own labor. ${ }^{36}$

\section{The money he brought in flowed right back out to the hospitalized sol- diers.}

Walt lived on $4^{1 / 2}$ St. in a room with a bed and a table and a broken down chair. He lived very frugally, mostly on bread and tea, expending everything he could get for the sol- 
diers. Emerson and other Boston friends sometimes sent him money for this purpose. He would stuff his pockets with things and go and distribute them to the sick soldiers. ${ }^{37}$

\section{As Whitman wrote,}

I provide myself with a quantity of bright new ten-cent and five-cent bills, and, when I think it incumbent, I give twenty-five or thirty cents, or perhaps fifty cents, and occasionally a still larger sum to some particular case. ${ }^{38}$

One night in Camden he lay in bed and thought of flies on eyes and open wounds, imagining a fly sucking nectar from his dead, staring eyes. He wondered if it had been worth it, the Leaves pressed down by the weight of the rest of his life. He pictured slabs of gray granite, as slow and heavy as he felt but more durable and less mutable, a final home built from a simplified version of a design by William Blake. But a small flexible fly could permeate even granite, humming through black interstices on an instinctual journey. The fly dies, the fly endures. He had seen one stuck in a piece of amber of unimaginable age, the amber a stone as light as hair. Even in granite his body would not last so long. When the Strong Deliveress came she might resemble a white-winged angel with big leafy feathers, or only a serene, iridescent fly. And the granite would outlast him, the monument a metaphor and mere reminder of the self that once walked the earth and saw itself all selves.

\section{North Carolina State University}

\section{NOTES}

1 The epigraph is from Emerson: Essays and Lectures (New York: Library of America, 1983), 346.

2 Specimen Days in Walt Whitman: Complete Poetry and Collected Prose (New York: Library of America, 1983), 735-736; hereafter cited as Poetry and Prose.

3 The Wound-Dresser, ed. R. M. Bucke (1897; rpt. New York: The Bodley Press, 1949), 41.

4 Specimen Days in Poetry and Prose, 774. The names before Reuben Farwell's are invented.

5 Poetry and Prose, 714, 717.

6 Poetry and Prose, 714.

7 "How come ... twang" is invented.

8 "Would you like ... drink" is invented.

9 "Come Up from the Fields Father," Drum-Taps, Poetry and Prose, 437. The original is in italics.

10 John Townsend Trowbridge, "Reminiscences of Walt Whitman," Atlantic Monthly Magazine, 89 (February 1902), 163-175, in Joel Myerson, ed., Whitman in His Own 
Time (Detroit: Omnigraphics, 1991), 176.

11 "I came to ... niggers" and "You don't know . . . white," are invented, as is Private Daniel Otis Wright.

12 See Michael P. Johnson and James L. Roark, Black Masters: A Free Family of Color in the Old South (New York: Norton, 1984). Corporal Martin Chandler and Private Nathaniel Washington are invented.

13 Poetry and Prose, 712.

14 Poetry and Prose, 713.

15 Poetry and Prose, 775.

16 C. Vann Woodward, "The Inner Civil War," The New York Review of Books (April 7, 1994), 36, a review of “. . the real war will never get in the books": Selections from Writers During the Civil War, ed. Louis P. Masur, and The Vacant Chair: The Northern Soldier Leaves Home by Reid Mitchell.

17 Elizabeth Leavitt Keller, Walt Whitman in Mickle Street (New York: Mitchell Kennerley, 1921), 137. The last sentence is John Swinton, in a letter to the New York Herald, April 1, 1876; quoted in Keller.

18 Poetry and Prose, 775.

19 Poetry and Prose, 776.

20 Poetry and Prose, 775-776.

21 "in Patent-office ... others": Poetry and Prose, 714; "Aquia creek railroad . . . Potomac": Poetry and Prose, 713.

22 Poetry and Prose, 713.

23 Poetry and Prose, 713.

24 Trowbridge in Myerson, 175-176.

25 Anonymous, quoting "an incident recorded in [Whitman's] diary," "Walt Whitman," London Advertiser [Ontario, Canada], June 5, 1880, 4; in Myerson, 23.

26 Mary Davis's headaches are mentioned in Keller, 87-88.

27 "You're only young once," "They won't be . . . long," and "Don't ever go . . . house" are imagined.

28 "Song of Myself," Poetry and Prose, 246.

29 "a bundle of . . . it" and "Hurry Mama! A . . . door," "Jimmie, watch if . . out": Keller, 39, quoting Donaldson.

30 "I could use . . . paper" and "You're as alive . . . be" are invented.

31 Thomas Donaldson, Walt Whitman the Man (New York: Francis P. Harper, 1896), 37.

32 Annie Dent is mentioned in John Johnston and J. W. Wallace, Visits to Walt Whitman in 1890 and 1891 (London: George Allen and Unwin, 1917; rpt. 1918), 42.

33 Ellen M. Calder, "Personal Recollections of Walt Whitman," Atlantic Monthly 99 (June 1907), 825-834; in Myerson, 201. 
34 Woodward, 37.

35 Reprint sold at Old Sturbridge Village, 1991.

36 Donaldson, 152.

37 John Burroughs, quoted in Clara Barrus, The Life and Letters of Fohn Burroughs (Boston: Houghton Mifflin, 1925), 1:107-110; in Myerson, 314.

38 Walt Whitman, "Gifts, Money, Discrimination," 1864; quoted in Donaldson, 157. 